\title{
Cheese yield in Brazil: state of the art
}

\author{
Danielle Cavalcanti SALES ${ }^{1}$, Adriano Henrique do Nascimento RANGEL ${ }^{1}$, Stela Antas URBANO ${ }^{1 *}$, \\ Kátia Cristina BORGES ${ }^{1}$, Júlio César de ANDRADE NETO ${ }^{1}$, Bruna Maria Emerenciano CHAGAS ${ }^{1}$
}

\begin{abstract}
This literature review discusses the concepts and factors that influence industrial cheese yield and compiles the latest studies conducted in Brazil involving this theme. In seeking to support managerial decision-making, cheese yield can be measured at the end of processing or estimated prior to this. In research and industry, measuring and estimating yield can be evaluated under the effect of processing, from different proportions and characteristics of ingredients (mainly milk quality), to processing factors involving the steps of the actual production (handling of the raw material and the curd coagulation conditions, salting, maturation, etc.) and the equipment. The number of Brazilian studies that have sought to answer questions about this topic in recent years was reasonable. The vast majority of them considered yield in its most basic aspect, which is obtained by measuring what was produced. Few studies used the perspective of prediction, indicating that there is room for a more empirical approach that allows for obtaining other types of answers regarding efficiency in the production of cheese, and which is shown as an opportunity for Brazilian research to advance.
\end{abstract}

Keywords: efficiency; equation; cheese production.

Practical Application: Understanding how cheese yield is evaluated and how Brazilian research has treated it.

\section{Introduction}

In order to obtain adequate efficiency in production management, the industrial sector needs to collect information about the use of raw materials. The yield in the production of dairy products allows for measuring the efficiency of milk use in the production process and can be used in experimental and industrial areas. This is because yield can give evidence of the productive success in practical and objective terms, behaving as a valuable tool for process improvement (Furtado, 2005; Abd El-Gawad \& Ahmed, 2011).

As industrial yield is directly related to the use of solid components in manufacturing of milk-derived (dairy) products, and therefore a loss of a part of it is the whey, the increased interest in the topic is not only motivated by economics, but also by environmental reasons, since whey residue is rich in nutrients, and can be a potential contaminant of water sources (Monteiro et al., 2007).

At the level of research and even in industries, the relations of $\mathrm{kg}$ of milk used $\div \mathrm{kg}$ mass produced or $\mathrm{kg}$ of cheese produced $\div 100 \mathrm{~kg}$ milk used, are the most common and popularly remembered when aiming to know the numerical value of cheese manufacturing yield (Furtado, 2005). However, studies in recent years have advanced so that calculation methods may be used, since there are many factors that have an effect on manufacturing yield (Cunningham, 2000; Furtado, 2005; Abd El-Gawad \& Ahmed, 2011).
Given the above, this study aimed to address conceptual aspects of industrial yield and factors that influence it, as well as analyzing study methodologies which have been developed in Brazil on this subject. For this, the present study addresses the conceptual and effectual aspects on industrial cheese yield (part I), taking into consideration the purpose of each research and their corresponding methods used for determining yield (part II).

\section{Methodology}

The research was developed through an integrative review, according to the method of Mendes et al. (2008), linking the empirical approach to a synthesis of the available evidence in the literature on the investigated subject, allowing for expanding the analysis possibilities of the scientific publications.

To accomplish "part (I)", a survey of the theoretical literature was performed with one sole criterion for selecting the bibliographic material - to contain information that would allow the empirical construction of this part of the research. For "part (II)", the consulted scientific articles were regarding studies developed in Brazil and published between the years 2005-2015, in English and Portuguese, in scientific journals resulting from Scielo Brazil, Science Direct and Google Scholar electronic databases, which correspond to the leading publications in the national context on the thematic of milk and cheese. Therefore, 
the key search words used were: "rendimento", "queijo", "yield", "cheese" and "cheese yield".

\section{Part I - Industrial cheese yield}

\subsection{Concept}

During cheese manufacturing, the efficiency of capturing milk constituents in mass is expressed by the manufacturing yield - a numerical value that facilitates analysis. In reality, all production processes of each industry naturally have their yield value, which makes sense only when compared to others as a reference, therefore representing a useful tool to indicate the efficiency of the current production process, considering the productivity, losses and even the potential for improvement.

Cheese yield expression is important in two main applications: economic control of production and the expression of dairy industry experiment results (Furtado, 2005; Abd El-Gawad \& Ahmed, 2011). It can be inferred that industrial yield enables the comparison of milk use efficiency from different production processes, livestock and animal species.

There are several methods to find cheese production yield. The best known and most employed in industries is actual or economic yield (Furtado, 2005), named so for indicating the cheese production cost through the actual value of a liter of the milk used. In this yield, only the ratio of the volume of cheese obtained from a given amount of milk is used.

However, this is not the single correct way to achieve the efficient use of raw materials (Cunningham, 2000; Abd El-Gawad \& Ahmed, 2011). Emmons et al. (1990), and Abd El-Gawad \& Ahmed (2011) have the understanding that the mathematical formulas used for studying cheese manufacturing efficiency should be divided into two areas: measurement and prediction.

Measurement formulas are based on the weight of the cheese that was produced or some of its components, such as non-fat dry extract, for example (Emmons et al., 1990). These measurement formulas calculate what was actually achieved in cheese, and therefore it identifies the "actual or economic" yield. Other expressions are associated with a yield known as "technical", involving factors other than volume of milk used and cheese produced. For example, considering the physical-chemical composition of milk, whey and/or cheese (Furtado, 2005).

Formulas for prediction are applied prior to the manufacturing process and are used to estimate the possible cheese yield based on the chemical characteristics of the milk and cheese whey or based on statistical formulas with coefficients calculated based on a large number of experiments already conducted (Emmons et al., 1990; Emmons \& Modler, 2010; Abd El-Gawad \& Ahmed, 2011). Formulas that reveal a possible numerical value of yield without the cheese actually being produced are called "theoretical".

Abd El-Gawad \& Ahmed (2011) divide prediction or "theoretical" formulas into: (1) Formulas based on theoretical considerations of solids distribution and moisture between the different phases of the components; (2) Multiple regression formulas based on fat and protein (casein); (3) Formulas that consider the levels of fat, casein and cheese moisture, a constant for salt effect and the presumed loss of casein; and (4) Formulas which focus on coagulation properties.

The prediction method contributes to studies in the industry with a view to standardize the qualitative characteristics of cheese, such as its composition and consequently its sensory characteristics (Emmons et al., 1990).

Emmons \& Modler (2010) confirmed through a prediction formula that predicted yield was equal to the actual yield and, therefore, they argue that laboratory analysis of cheese protein and fat are not always necessary to discover yield, which is advantageous in carrying out research as it allows for saving time and financial resources.

\subsection{Factors influencing cheese yield}

As discussed by Cunningham (2000), Furtado (2005) and Abd El-Gawad \& Ahmed (2011), it is proven that several factors have an effect on cheese yield and the yields of other dairy products.

The proportion of milk components along with the type and composition of cheese made are the primary factors directly linked to industrial yield (Furtado \& Pombo, 1979; Abd El-Gawad \& Ahmed, 2011). This is because the maximum possible quantity of milk solids is expected to be retained in the cheese, allowing for a smaller ratio of milk volume used in manufacturing one kilogram of the derivative (dairy product). Thus, it is clear that both the inherent processing factors such as the factors related to the animal itself (production and quality of milk) may incur losses in the use of solids, and consequently in cheese yield.

Intrinsic factors to the animal that are relevant to the issue at hand are those directly associated to the quality of the milk produced. In short, basically genetic, physiological and nutritional factors such as species, breed, chemical composition of the offered diet, lactation stage, female age, birth order and variability between individuals (Tripaldi et al., 2003).

Hühn et al. (1986), for example, came to the conclusion that it is economically feasible to produce products from buffalo milk instead of cow's milk, only by calculating the economic yield using the ratio of the amount of product obtained and the amount of raw material used (Table 1). This advantage in the production of products is mainly due to higher proportion of solids from buffalo milk compared to cow's milk.

Table 1. Industrial yield of buffalo milk and cow milk.

\begin{tabular}{lccc}
\hline \multirow{2}{*}{ Products } & \multicolumn{2}{c}{ Yield (L milk/kg cheese) } & \multirow{2}{*}{$\begin{array}{c}\text { Raw material } \\
\text { savings }^{1}(\%)\end{array}$} \\
\cline { 2 - 3 } & Buffalo & Cow & 41 \\
Marajoara Requeson & 6.00 & $10.00-12.00$ & 40 \\
Yogurt & 1.20 & 2.00 & 39 \\
Mozzarella & 5.50 & $8.00-10.00$ & 35 \\
CPATU cheese & 4.56 & $6.00-8.00$ & 29 \\
Milk caramel & 2.56 & 3.50 & 20 \\
Provolone & 7.43 & $8.00-10.00$ & 29 \\
\hline
\end{tabular}

${ }^{1}$ Economy of milk to produce $1 \mathrm{~kg}$ of buffalo milk product. Source: Adapted from Hühn et al. (1986). 
It is worth noting that the health of the mammary gland is very important when it comes to the quality of milk, since the microbiological and immune aspects invariably expressed by the total bacterial count and somatic cells have high ability to change milk constituents and cheese yield (Oliveira et al., 2006; Andreatta et al., 2009; Mikulec et al., 2012; Montanhini et al., 2013; Coelho et al., 2014).

Regarding factors resulting from processing, the following can be emphasized: homogenization and heat treatment of milk; temperature and $\mathrm{pH}$ of the milk throughout the processing; type of coagulant used; clotting time; cutting form; curd firmness to cut; handling and cleaning (dilution) of the curd systems; salting and loss of moisture during maturation; method employed for incorporating proteins in cheese (use of cryoprecipitate technology, use of ultra-filtered milk or addition of denatured milk whey protein) (Cunningham, 2000; Abd El-Gawad \& Ahmed, 2011; Santos et al., 2013).

As success in the final production of cheese depends on smooth running of the industry process, milk coagulation properties and also firmness of the curds obtained are closely related factors to the industrial yield. Stocco et al. (2015) confirmed these properties suffer significant effects of temperature and acidification in the process, as well as the amount and type of curd and standardization of fat during manufacturing.

Other factors that when viewed in isolation are not considered critical, but when occurring together can also compromise production efficiency, being: milk storage conditions (prolonged time at room temperature and/or cooling); excess agitation and pumping of milk; lack of added calcium chloride to milk intended for cheese production; premature cutting of the curd; defects in the cut caused by using inadequate equipment; lack of control of the cheese moisture content; and inadequate measurement systems and equipment calibration (Cunningham, 2000).

The latter author also points out that, although often neglected by cheese industries, the eight factors mentioned above can together cause negative and significant global impact, reaching losses of $20 \%$ or more in the final production volume.

Although many factors are involved in the manufacture of cheese and its efficiency, as the process occurs through the recovery of milk solids in mass (curd), the yield primarily depends on the chemical composition of milk. When the milk has high content of total solids, an increased manufacturing yield is favored (Garcia et al., 2008), since there is a chance these solids are retained in the cheese mass.

In the field of the dairy production industry, the adverse effects of mammary gland infection is explained by the fact that the rise in SCC is directly related to the decrease in productivity, changes in chemical composition of milk (fat, lactose and casein), in the activity of enzymes in the clotting time, and the yield and quality of milk products (Andreatta et al., 2009; Mikulec et al., 2012; Montanhini et al., 2013; Coelho et al., 2014; Ribas et al., 2014).

Sollecito et al. (2011) see changes in milk composition as a problem for the industry, since they hinder yield, quality and stability (shelf life) of the derivatives. Thus, the quality of milk has been quite a profound topic in recent years, both in order to monitor the updates/progress of the laws and requirements for food safety, as well as to seek greater industrial efficiency.

Because the measurement of industrial yield considers the cheese weight produced from a certain amount of milk, the water content (moisture) of cheese can mask reading in terms of total solids of cheese yield. A cheese with above optimum moisture values has high water activity (Furtado, 2005), increasing the chance of changes in visual appearance and an undesired proliferation of spoilage microorganisms in the product. That is to say, in addition to masking the use of milk solids in the process, high humidity can bring lower quality and shelf life of dairy products and harm the industry's image to the consumer. Therefore, it is important to consider the humidity of the product in the calculation of cheese yield.

\section{Part II - Brazilian studies}

A total of 13 scientific articles that met the criteria used in this review were accounted for, being contrary to what one might expect, since the considered databases often contribute studies that broadly deal with the thematic of milk and its derivatives.

\subsection{Research objectives}

Articles included in this study were aimed at several objectives; however, the manufacturing yield was the overall goal of half of the articles found. The type of cheese and the animal species also varied among the studies (Table 2), where the majority involved Minas cheese made from cow's milk.

\subsection{Compilation of methods used to calculate the industrial cheese yield}

In all studies reviewed, the formulas used had already been developed by other authors (Table 3 ).

In general, methods for calculating both economic and technical real yield were employed. Only one study used the prediction method, showing that most of the research sought to directly answer questions by measuring and calculating the actual industrial yield, without resorting to prediction.

\section{Actual yield}

\section{Economic yield}

It is the most practical method of calculation because it is based on the amount of milk used in processing and the amount of cheese/mass obtained after manufacturing.

The most usual equation for economic yield is that which can be used for any type of cheese which is produced from the curd, and it considers the amount of cheese or curd made from a certain quantity of milk. The formulas involving this reasoning are those used by Katili et al. (2006), Damián et al. (2008), Oliveira et al. (2008), Silva et al. (2012), and Santos et al. (2013) (Equation 1), Andreatta et al. (2009) (Equation 1.1) and Martins et al. (2012) (Equation 1.2).

$\mathrm{Y}(\mathrm{kg} / 100 \mathrm{~L})=\mathrm{P} \div \mathrm{L}$ 
Table 2. Objectives of the compiled work.

\begin{tabular}{|c|c|}
\hline Author & Objective \\
\hline Neves-Souza \& Silva (2005) & Evaluate the effect of different anticoagulants on minas fresh cheese yield. \\
\hline Katili et al. (2006) & $\begin{array}{l}\text { Evaluate a cheese obtained from soft mass of mixed coagulation, matured by Penicillium candidum fungus } \\
\text { using milk frozen by slow or fast processes and the manufacture of the same cheese using curd frozen by } \\
\text { the same processes. }\end{array}$ \\
\hline Ribeiro et al. (2007) & $\begin{array}{l}\text { Evaluate production, composition and yield (of cheese manufacturing) of Santa Inês sheep milk treated or } \\
\text { untreated with oxytocin. }\end{array}$ \\
\hline Damián et al. (2008) & $\begin{array}{l}\text { Evaluate components, casein fractions and yield in production of goat cheese milk from Saanen and Anglo- } \\
\text { Nubiana breeds. }\end{array}$ \\
\hline Oliveira et al. (2008) & Evaluate the yield of lactating buffaloes fed different sources of fat. \\
\hline Andreatta et al. (2009) & $\begin{array}{l}\text { Evaluate the effect of using milk with different somatic cell counts (SCC) on the quality of minas fresh } \\
\text { cheese. }\end{array}$ \\
\hline Conceição et al. (2009) & $\begin{array}{l}\text { Evaluate the feasibility of ricotta production using calcium chloride replacing lactic acid, as well as } \\
\text { determining the production yield, physico-chemical, microbiological and sensory characteristics of the } \\
\text { obtained cheese. }\end{array}$ \\
\hline Perrone et al. (2010) & $\begin{array}{l}\text { Determine the composition and cheese yield of prato cheese made from concentrated milk by vacuum } \\
\text { evaporation. }\end{array}$ \\
\hline Marques et al. (2011) & $\begin{array}{l}\text { Evaluate physicochemical and sensory characteristics of standard Minas cheese produced with probiotic } \\
\text { cultures. }\end{array}$ \\
\hline Martins et al. (2012) & $\begin{array}{l}\text { Evaluate physico-chemical and sensory quality and fatty acid profile of minas fresh cheese produced with } \\
\text { milk from crossbred cows fed different forage. }\end{array}$ \\
\hline Silva et al. (2012) & $\begin{array}{l}\text { Verify the influence of raw milk SCC and TBC in cheese yield, using scaled-down method, and evaluate the } \\
\text { theoretical prediction of cheese yield. }\end{array}$ \\
\hline Santos et al. (2013) & $\begin{array}{l}\text { Evaluate the effect of different } \mathrm{pH} \text { conditions and the addition of calcium }\left(\mathrm{CaCl}_{2}\right) \text { on yield, nutrient } \\
\text { retention in produced clots and the texture of cured Minas cheese. }\end{array}$ \\
\hline Fava et al. (2014) & $\begin{array}{l}\text { Evaluate the effect of milk cooling and freezing for seven days, on the yield of the curd produced from } \\
\text { sheep milk and on the physical characteristics of the obtained whey. }\end{array}$ \\
\hline
\end{tabular}

Table 3. Methodological aspects of the analyzed studies.

\begin{tabular}{|c|c|c|c|c|c|c|}
\hline Authors & Evaluated factor & Type of cheese & Species & Equation $^{1}$ & Type $^{2}$ & Method's Authorship $^{3}$ \\
\hline \multirow{2}{*}{$\begin{array}{l}\text { Neves-Souza \& Silva } \\
(2005)\end{array}$} & \multirow{2}{*}{ Different types of coagulants } & \multirow{2}{*}{ Minas fresh } & \multirow{2}{*}{ Cow } & 1.4 & $\mathrm{M} / \mathrm{E}$ & Rossi et al. (1998) \\
\hline & & & & 3 & $\mathrm{M} / \mathrm{T}$ & Saboya et al. (1998) \\
\hline Katili et al. (2006) & $\begin{array}{l}\text { Maturation process by Penicillium } \\
\text { candidum fungus, frozen milk and } \\
\text { frozen curd }\end{array}$ & Bougon Frances & Goat & 1.1 & $\mathrm{M} / \mathrm{E}$ & NR \\
\hline Ribeiro et al. (2007) & Treatment with oxytocin & $\begin{array}{l}\text { Azeitão, pecorino } \\
\text { and } \\
\text { roquefort from Sheep }\end{array}$ & Sheep & 1.4 & $\mathrm{M} / \mathrm{E}$ & NR \\
\hline Damián et al. (2008) & Different breeds & Cheese & Goat & 1.1 & $\mathrm{M} / \mathrm{E}$ & NR \\
\hline Oliveira et al. (2008) & Different sources of lipids & Mozzarella & Buffalo & 1.1 & $\mathrm{M} / \mathrm{E}$ & NR \\
\hline Andreatta et al. (2009) & Different levels of somatic cell count & Minas fresh & Cow & 1.2 & $\mathrm{M} / \mathrm{E}$ & Fox et al. (2000) \\
\hline \multirow[b]{2}{*}{ Conceição et al. (2009) } & \multirow{2}{*}{$\begin{array}{l}\text { Replacing calcium chloride by lactic } \\
\text { acid }\end{array}$} & \multirow[b]{2}{*}{ Ricotta } & \multirow[b]{2}{*}{ Cow } & 1.4 & $\mathrm{M} / \mathrm{E}$ & NR \\
\hline & & & & 3 & $\mathrm{M} / \mathrm{T}$ & Furtado (2005) \\
\hline Marques et al. (2011) & Probiotic cultures & probiotic Minas & Cow & 3 & $\mathrm{M} / \mathrm{T}$ & Furtado (2005) \\
\hline \multirow{2}{*}{ Martins et al. (2012) } & \multirow{2}{*}{ Animal feed with different forage } & \multirow{2}{*}{ Minas fresh } & \multirow{2}{*}{ Cow } & 1.3 & $\mathrm{M} / \mathrm{E}$ & Andreatta et al. (2009) \\
\hline & & & & 2 & $\mathrm{M} / \mathrm{E}$ & Oliveira (1986) \\
\hline \multirow[b]{2}{*}{ Silva et al. (2012) } & \multirow{2}{*}{$\begin{array}{l}\text { SCC and Total Bacterial Count of } \\
\text { raw milk }\end{array}$} & \multirow[b]{2}{*}{ NR } & \multirow[b]{2}{*}{ Cow } & 1.1 & $\mathrm{M} / \mathrm{E}$ & NR \\
\hline & & & & 5 & $\mathrm{P} / \mathrm{T}$ & $\begin{array}{l}\text { Van Slyke \& Publow } \\
(1921)\end{array}$ \\
\hline Santos et al. (2013) & $\mathrm{pH}$ and calcium addition & Cured Minas & Cow & 1.1 & $\mathrm{M} / \mathrm{E}$ & NR \\
\hline Fava et al. (2014) & $\begin{array}{l}\text { Types of storage to obtain milk } \\
\text { curds }\end{array}$ & Milk Curds & Sheep & 1.4 & $\mathrm{M} / \mathrm{E}$ & Silveira \& Abreu (2003) \\
\hline
\end{tabular}

NR: not reported in the article. ${ }^{1}$ Order as described in the text. ${ }^{2}$ M: Measuring, P: Prediction, E: Economic, T: Technical. ${ }^{3}$ Author of the equation cited in the article. Source: Adapted from the cited authors. 
$\mathrm{Y}(\%)=[\mathrm{P} \div(\mathrm{L}+$ weight of ingredients $)] \times 100$

$\mathrm{Y}(\mathrm{kg} / \mathrm{kg})=(\mathrm{L}+$ weight of ingredients $) \div \mathrm{P}$ after packaging

where: $\mathrm{P}=$ cheese production $(\mathrm{kg}) ; \mathrm{L}=$ volume of milk used (liters).

Neves-Souza \& Silva (2005), Ribeiro et al. (2007), Conceição et al. (2009), Marques et al. (2011) and Fava et al. (2014) relate the volume of milk used to make one kilogram of cheese or curd, in order to measure industrial yield, according to Equation 1.3.

$\mathrm{Y}(\mathrm{L} / \mathrm{kg})=\mathrm{L} \div \mathrm{P}$

where: $\mathrm{P}=$ cheese production $(\mathrm{kg}) ; \mathrm{L}=$ volume of milk used (liters).

\section{Technical yield}

The calculation of technical yield can be obtained by considering the content of constituents (particularly the total solids, fat and/or protein) and humidity retained in the cheese. This method allows for comparing different yields of the same type of cheese, even if they have different physical and chemical compositions (Furtado, 2005).

Martins et al. (2012) and Conceição et al. (2009) obtained adjusted yield for moisture (Equation 2), which is applied to batches of cheese with different moisture (Oliveira, 1986).

$$
\mathrm{Yc}(\mathrm{Kg} / \mathrm{kg} \mathrm{A})=\mathrm{Y}^{\prime} \times[(100-\% \mathrm{M}) /(100-\% \mathrm{Ms})]
$$

where: $\mathrm{Y}^{\prime}=$ actual yield; $\% \mathrm{M}=$ moisture content; $\% \mathrm{Ms}$ = supposed common moisture content between cheeses.

Neves-Souza \& Silva (2005), Conceição et al. (2009), Perrone et al. (2010) and Marques et al. (2011) (Equation 3) obtained cheese yield by the ratio of the amount of total cheese solids (before Salting)/liter of milk, known as GL coefficient equation:

$$
\mathrm{Y}(\mathrm{g} \mathrm{TS} / \mathrm{L})=(\mathrm{P} \times \mathrm{TS}) \div \mathrm{L}
$$

where: TS = total solids of cheese $(100$ - \% moisture $) ; \mathrm{P}=$ Cheese production $(\mathrm{kg}) ; \mathrm{L}=$ milk volume $(\mathrm{L})$.

The above formula can consider adjusting the desired moisture content, when you want to compare cheese, assuming they have the same moisture. For this, Perrone et al. (2010) used the following expression (Equation 4):

$\mathrm{Yc}(\mathrm{L} / \mathrm{kg} \mathrm{A})=[\mathrm{V} \times(100-\mathrm{Ms})] \div(\mathrm{P} \times \mathrm{TS})$

where: $\mathrm{Yc}=$ adjusted yield; $\mathrm{Ms}=\%$ supposed common humidity between cheeses.

\section{Predicted yield}

The equation used by Silva et al. (2012) considers the calculation of yield based on milk components and moisture (Equation 5):

$$
Y=(0.93 \times \% G+\% C-0.1) \times 1.09 /[(100-\% M) / 100]
$$

where: $\% \mathrm{G}=$ fat content of milk; $\% \mathrm{C}=$ Casein content of milk; $\mathrm{M} \%=$ moisture content of milk.

It is observed that researchers who seek to evaluate the influence of factors on yield are more likely to employ measurement formulas. This result may be linked to the fact that Brazilian research on yield is having more frequent accomplishment recently. This habit has grown with the need for compliance with the laws in force in the case of using different types of coagulants, for example; and mainly due to the progressive search for increased productivity and efficiency, reducing losses and achieving more profitability. The major focus of researchers in applying the yield from the economic point of view reinforces this assumption.

Several authors have taken advantage of more than one method to achieve the production yield of cheese. Perhaps in forthcoming work there may be more technical and more in-depth concerns regarding cheese-making yield, a path being traveled by more researchers from the center-south of the country, mainly aimed at Minas cheese manufacturing from bovine milk.

\section{Conclusions}

Studying milk yield allows for efficiency in cheese production and is identified in an industrial or scientific context when there is concern in measuring the effect of different methods, ingredients or types of raw material (milk) used in the process; or even to support decision-making aimed at management improvements. The causes of variation in industrial cheese yield are related to the quality of milk; as well as the processing itself, with factors involving the characteristics of the used ingredients, the actual production steps (raw material handling and curd coagulation conditions, salting, maturation, etc.) and equipment.

The included studies mostly used the actual economic yield calculation method, indicating that there are few studies that envision the prediction of industrial cheese yield, which is an opportunity for future Brazilian research.

The fact that some of the equations used by national studies originate from international publications indicates that the subject in question has already been approached in greater depth outside Brazil, including the use of other methods for measuring and predicting the cheese manufacturing yield. Therefore, it is suggested that this issue be reviewed in an international context.

\section{References}

Abd El-Gawad, M. A. M., \& Ahmed, N. S. (2011). Cheese yield as affected by some parameters review. Acta Scientiarum Polonorum: Technologia Alimentaria, 10(2), 131-153.

Andreatta, E., Fernandes, A. M., Santos, M. V., Mussarelli, C., Marques, M. C., Gigante, M. L., \& Oliveira, C. A. F. (2009). Quality of minas frescal cheese prepared from milk with different somatic cell counts. Pesquisa Agropecuária Brasileira, 44(3), 320-326. http://dx.doi. org/10.1590/S0100-204X2009000300014.

Coelho, K. O., Mesquita, A. J., Machado, P. F., Lage, M. E., Meyer, P. M., \& Reis, A. P. (2014). Efeito da contagem de células somáticas sobre 
o rendimento e a composição físico-química do queijo muçarela. Arquivo Brasileiro de Medicina Veterinária e Zootecnia, 66(4), 12601268. http://dx.doi.org/10.1590/1678-7616.

Conceição, A. C., Silva, M. R., Oliveira, V. S., Soares, B. G., Martins, M. L., \& Martins, A. D. O. (2009). Avaliação da utilização de cloreto de cálcio em substituição ao ácido lático para fabricação de ricota. Revista do Instituto de Laticínios Cândido Tostes, 64(369), 32-38.

Cunningham, A. I. (2000). Optimización de rendimiento y aseguramiento de inocuidad en la industria de quesería: una guía para la pequeña $y$ mediana empresa (171p.). Washington: Organización de los Estados Americanos.

Damián, J. P., Sacchi, I., Reginensi, S., De Lima, D., \& Bermúdez, J. (2008). Cheese yield, casein fractions and major components of milk of Saanen and Anglo-Nubian dairy goats. Arquivo Brasileiro de Medicina Veterinária e Zootecnia, 60(6), 1564-1569. http://dx.doi. org/10.1590/S0102-09352008000600040.

Emmons, D. B., Ernstrom, C. A., Lacroix, C., \& Verret, P. (1990). Predictive formulas for yield of cheese from composition of milk: a review. Journal of Dairy Science, 73(6), 1365-1394. http://dx.doi. org/10.3168/jds.S0022-0302(90)78803-0.

Emmons, D. B., \& Modler, H. W. (2010). Invited review: a commentary on predictive cheese yield formulas. Journal of Dairy Science, 93(12), 5517-5537. http://dx.doi.org/10.3168/jds.2010-3262. PMid:21094725.

Fava, L. W., Külkamp-Guerreiro, I. C., \& Pinto, A. T. (2014). Rendimento de coalhada obtida a partir de leite fresco, resfriado e congelado de ovelhas da raça Lacaune e caracterização física do soro obtido. Ciência Rural, 44(5), 937-942. http://dx.doi.org/10.1590/S010384782014000500028.

Fox, P. F., Guinee, T. P., Cogan, T. M., \& McSweeney, P. L. H. (2000). Fundamentals of cheese science (588 p.). Gaithersburg: Aspen Publishers.

Furtado, M. M. (2005). Principais problemas em queijos: causas e prevenções (200 p.). São Paulo: Fonte Comunicação e Editora.

Furtado, M. M., \& Pombo, A. F. W. (1979). Fabricação de queijo prato e minas: estudo do rendimento. Parte I - determinação das cifras de transição. Revista do Instituto de Laticínios Cândido Tostes, 34(205), 1-48.

Garcia, R. V., Falcão, R. S., Fo., Duarte, T. F., Pessoa, T. R. B., \& Queiroga, R. C. R. E. (2008). Aceitabilidade e preferência sensorial do queijo de coalho de leite búfala, de leite cabra e de leite de vaca. Revista do Instituto de Laticínios Cândido Tostes, 63(363), 12-16.

Hühn, S., Lourenço, J. B., Jr., Carvalho, L. O. D. M., Nascimento, C. N. B., \& Vieir, L. C. (1986). Aproveitamento do leite de búfala em produtos derivados. In Anais do $1^{\circ}$ Simpósio do Trópico Úmido (pp. 265-269), Belém, PA. Belém: EMBRAPA/CPATU.

Katili, L. M., Bonassi, I. A., \& Roca, R. O. (2006). Aspectos físico-químicos e microbianos do queijo maturado por mofo obtido da coagulação mista com leite de cabra congelado e coalhada congelada. Ciência e Tecnologia de Alimentos, 26(4), 740-743. http://dx.doi.org/10.1590/ S0101-20612006000400004.

Marques, K. A., Ferreira, R. P., Martins, A. D. O., Soares, B. G., Martins, M. L., \& Martins, J. M. (2011). Características físico-químicas e sensoriais de queijo minas padrão probiótico. Revista do Instituto de Laticínios Cândido Tostes, 66(378), 17-25.

Martins, S. C. S. G., Rocha, V. R., Jr., Caldeira, L. A., Reis, S. T., Barros, I. C., Oliveira, J. A., Santos, J. F., \& Silva, G. W. V. (2012). Rendimento, composição e análise sensorial do queijo minas frescal fabricado com leite de vacas mestiças alimentadas com diferentes volumosos. Revista Brasileira de Zootecnia, 41(4), 993-1003. http://dx.doi. org/10.1590/S1516-35982012000400023.
Mendes, K. D. S., Silveira, R. C. P., \& Galvao, C. M. (2008). Revisão integrativa: método de pesquisa para a incorporação de evidências na saúde e na enfermagem. Texto \& Contexto: Enfermagem, 17(4), 758-764. http://dx.doi.org/10.1590/S0104-07072008000400018.

Mikulec, D. P., Petrovic, M. P., \& Raycheva, E. (2012). Effect of variations in somatic cell count on cheese yield on the stara planina in serbia. International Journal of Research and Reviews in Applied Sciences, 12(1), 57-60.

Montanhini, M. T. M., Moraes, D. H. M., \& Montanhini, R., No. (2013). Influência da contagem de células somáticas sobre os componentes do leite. Revista do Instituto de Laticínios Cândido Tostes, 68(392), 18-22. http://dx.doi.org/10.5935/2238-6416.20130024.

Monteiro, A. A., Pires, A. C. S., \& Araújo, E. A. (2007). Tecnologia de produção de derivados de leite (Cadernos Didáticos, Vol. 120, 81 p.). Viçosa: Editora UFV.

Neves-Souza, R. D., \& Silva, R. S. S. F. (2005). Estudo de custo-rendimento do processamento de queijos tipo minas frescal com derivado de soja e diferentes agentes coagulantes. Ciência e Tecnologia de Alimentos, 25(1), 170-174. http://dx.doi.org/10.1590/S0101-20612005000100028.

Oliveira, J. S. (1986). Queijo: fundamentos tecnológicos (2nd ed., 146 p.). Campinas: Unicamp.

Oliveira, R. L., Bagaldo, A. R., Ladeira, M. M., Barbosa, M. A. A. F., Oliveira, R. J. C., \& Oliveira, G. J. C. (2008). Desempenho produtivo e custos com alimentação de búfalas lactantes submetidas a dietas com diferentes fontes de lipídeo. Revista Brasileira de Zootecnia, 37(8), 1503-1508. http://dx.doi.org/10.1590/S1516-35982008000800024.

Oliveira, W. P., Oliveira, A. N., Nicolau, E. S., Mesquita, A. J., Neves, R. B., \& Fernandes, S. D. (2006). Impacto da contagem de células somáticas elevada no rendimento de queijo mussarela. In Anais do $2^{\circ}$ Congresso Brasileiro de Qualidade do Leite, Goiânia, GO. Retrieved from http://www.terraviva.com.br/IICBQL/p010.pdf

Perrone, I. T., Pereira, J. P. F., Magalhães, F. A. R., Costa-Junior, L. C. G., Paula, J. C. J., \& Sobral, D. (2010). Determinação da composição e do rendimento de queijo prato obtido a partir de leite concentrado por evaporação a vácuo. Revista do Instituto de Laticínios Cândido Tostes, 65(376), 35-41.

Ribas, N. P., Rossi, P., Jr., Andrade, U. V. C., Valotto, A. A., Jesus, C. P., \& Almeida, M. C. (2014). Escore de células somáticas e sua relação com os componentes do leite em amostras de tanque no estado do paraná. Archives of Veterinary Science, 19(3), 14-23. http://dx.doi. org/10.5380/avs.v19i3.32490.

Ribeiro, L. C., Pérez, J. R. O., Carvalho, P. H. A., Silva, F. F., Muniz, J. A., Oliveira, G. M., Jr., \& Souza, N. V. (2007). Produção, composição e rendimento em queijo do leite de ovelhas Santa Inês tratadas com ocitocina. Revista Brasileira de Zootecnia, 36(2), 438-444. http:// dx.doi.org/10.1590/S1516-35982007000200022.

Rossi, D. A., Abreu, L. R., Furtado, M. M., \& Moura, C. J. (1998). Utilização do coalho bovino e coagulantes microbiano e genético na composição e rendimento do queijo Minas Frescal. Revista do Instituto do Laticínio Candido Tostes, 53(305), 8-14.

Saboya, L. V., Oliveira, A. J., Furtado, M. M., \& Spadoti, L. M. (1998). Efeitos físico-químicos da adição de leite reconstituído na fabricação de queijo minas frescal. Ciência e Tecnologia de Alimentos, 18(4), 368-378. http://dx.doi.org/10.1590/S0101-20611998000400002.

Santos, B. N. C., Silva, C. C. C. V., Domingues, J. R., Cortez, M. A. S., Freitas, D. D. G. C., Chiappini, C. C. J., \& Araújo, K. G. L. (2013). Effect of calcium addition and $\mathrm{pH}$ on yield and texture of Minas cured cheese. Arquivo Brasileiro de Medicina Veterinária e Zootecnia, 65(2), 601-609. http://dx.doi.org/10.1590/S0102-09352013000200042. 
Silva, N. M. A., Bastos, L. P. F., Oliveira, D. L. S., Oliveira, M. C. P. P., \& Fonseca, L. M. (2012). Influence of somatic cell count and total bacterial counts of raw milk in cheese yield using small-scale methodology. Arquivo Brasileiro de Medicina Veterinária e Zootecnia, 64(5), 1367-1372. http://dx.doi.org/10.1590/S0102-09352012000500038.

Silveira, P. R., \& Abreu, L. R. (2003). Rendimento e composição físicoquímica do queijo prato elaborado com leite pasteurizado pelo sistema HTST e injeção direta de vapor. Ciência e Agrotecnologia, 27(6), 1340-1347. http://dx.doi.org/10.1590/S1413-70542003000600019.

Sollecito, N. V., Lopes, L. B., \& Leite, R. C. (2011). Contagem de células somáticas, perfil de sensibilidade antimicrobiana e microrganismos isolados de mastites em búfalos: uma breve revisão. Revista Brasileira de Medicina Veterinária, 33(1), 18-22.
Stocco, G., Cipolat-Gotet, C., Cecchinato, A., Calamari, L., \& Bittante, G. (2015). Milk skimming, heating, acidification, lysozyme, and rennet affect the pattern, repeatability, and predictability of milk coagulation properties and of curd-firming model parameters: a case study of Grana Padano. Journal of Dairy Science, 98(8), 1-16. http://dx.doi.org/10.3168/jds.2014-9146. PMid:26051315.

Tripaldi, C., Terramoccia, S., Bartocci, M., Angelucci, M., \& Danese, V. (2003). The effects of the somatic cell count on yield, composition and coagulating properties of Mediterranean buffalo milk. AsianAustralasian Journal of Animal Sciences, 16(5), 738-742. http:// dx.doi.org/10.5713/ajas.2003.738.

Van Slyke, L. L., \& Publow, C. A. (1921). The science and practice of cheese making (487 p.). New York: Orange Judd Company. 